\title{
ANALISIS LINGKUNGAN INTERNAL DAN EKSTERNAL PADA USAHA KEDAI KOPI KADAKA CAFETARIA MENGGUNAKAN QSPM
}

\section{INTERNAL AND EXTERNAL ENVIRONMENTAL ANALYSIS IN KADAKA CAFETARIA COFFEE SHOP USING QSPM}

\author{
Nadya Hasna Latifa, Dini Rochdiani* \\ Program Studi Agribisnis Fakultas Pertanian Universitas Padjadjaran \\ Jl. Raya Bandung-Sumedang, Jawa Barat 45363 \\ *Email: dini.rochdiani@yahoo.co.id ${ }^{2}$ \\ (Diterima 25-08-2019; Disetujui 30-08-2019)
}

\begin{abstract}
ABSTRAK
Tanaman kopi merupakan tanaman perkebunan yang sudah ada dari sejak dahulu menjadi tanaman yang di budidayakan. Dewasa ini, minuman kopi tidak lagi sekedar untuk dikonsumsi tetapi bisa menjadi pelengkap aktifitas sehari-hari. Jumlah konsumsi kopi diperkirakan akan terus meningkat seiring meningkatnya pendapatan kalangan kelas menengah sehingga membuat para pebisnis kedai kopi menjadi yakin untuk menjalankan usahanya. KADAKA Cafetaria merupakan salah satu kedai kopi baru yang mengalami permasalahan dalam penjualannya. Selain itu, terdapat pula pesaing sejenis di sekitarnya. Dengan demikian, perlu diketahuinya alternatif strategi pemasaran yang dapat digunakan kedai kopi KADAKA Cafetaria sehingga dapat menghadapi persaingan. Desain pada penelitian ini menggunakan desain kualitatif dan teknik penelitian studi kasus. Alat analisis yang digunakan yaitu menggunakan matriks IFE, EFE, IE, SWOT, lalu QSP. Hasil dari matriks IE menunjukkan bahwa perusahaan tersebut berada pada posisi tumbuh dan bina. Empat strategi alternatif dirumuskan dari hasil matriks SWOT dan QSP dengan strategi prioritas pertama adalah dengan meningkatkan kegiatan promosi.
\end{abstract}

Kata kunci: Kopi, Kedai Kopi, SWOT, QSPM

\section{ABSTRACT}

Coffee plants are plantations that have existed for a long time ago to be cultivated plants. Today, coffee drinks are no longer just for consumption but can be complementary to daily activities. The amount of coffee consumption is expected to continue to increase along with the increasing income of the middle class, making coffee shop businesspeople sure to run their businesses. KADAKA Cafetaria is one of the new coffee shops that have problems with its sales. Also, there are similar competitors in the vicinity. Thus, it is necessary to know the alternative marketing strategies that can be used by KADAKA Cafetaria coffee shops so they can face competition. The design in this study uses qualitative design and case study research techniques. The analysis tool used is using the IFE, EFE, IE, SWOT, then QSP matrices. The results of the IE matrix show that the company is in a position to grow and develop. Four alternative strategies are formulated from the results of the SWOT and QSP matrices with the priority strategy is to increase promotional activities.

Keywords: Coffee, Coffee Shop, SWOT, QSPM

\section{PENDAHULUAN}

Tanaman kopi (Coffea L.) merupakan tanaman perkebunan yang sudah dari sejak dahulu menjadi tanaman yang dibudidayakan. Jenis tanaman kopi yang biasa dibudidayakan yaitu Kopi Arabika (Coffea Arabica) dan Kopi

Robusta (Coffea canephora). Menurut 
Siswoputranto (1993), jenis Kopi Arabika memiliki kualitas cita rasa tinggi dan kadar kafein lebih rendah dibandingkan dengan jenis Robusta, sehingga kopi jenis Arabika memiliki harga yang lebih mahal. Budidaya kopi dikembangkan di Indonesia sudah hampir tiga abad, yaitu sejak tanaman kopi untuk pertama kali dimasukan ke pulau Jawa di zaman Hindia Belanda pada tahun 1996 (Afriyanti, 2016). Bibit tanaman Kopi Arabika pertama kali dimasukkan oleh Gubernur Belanda asal dari MalabarIndia dan diterima oleh pemerintah Bogor untuk percobaan penanaman, dan kemudian berhasil (Siswoputranto, 1993).

Dewasa ini, minuman kopi tidak lagi menjadi sekedar untuk dikonsumsi, tetapi minuman kopi kini bisa menjadi pelengkap aktifitas sehari-hari seperti mengerjakan tugas, rapat, reuni teman lama, dan lain-lain. Secara tidak sadar, minuman kopi sudah menjadi gaya hidup bagi beberapa kalangan masyarakat dari murid sekolah menengah hingga pekerja kantor pun menggemari minuman kopi yang sudah sangat bervariasi.

Jumlah konsumsi kopi diperkirakan akan terus meningkat setiap tahunnya seiring meningkatnya pendapatan masyarakat kelas menengah. Tingkat konsumsi kopi di Indonesia dapat dilihat pada Gambar 1.

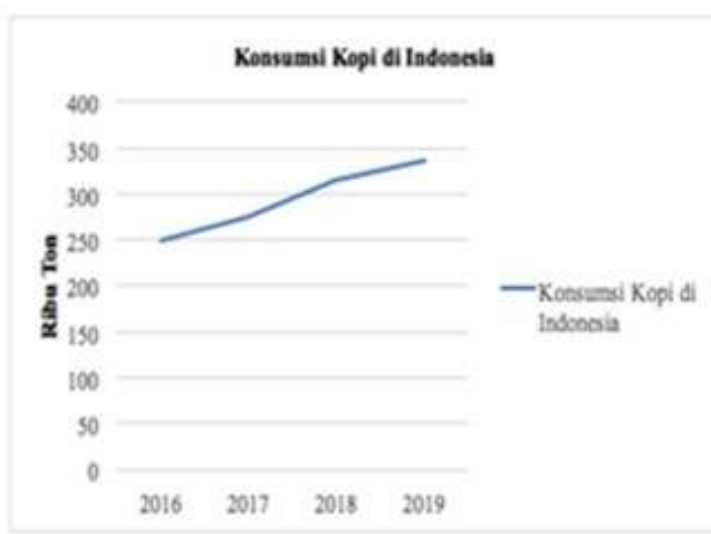

Gambar 1. Konsumsi Kopi di Indonesia (Kementrian Pertanian, 2018)

Berdasarkan data pada Gambar 1. di atas, dapat diketahui bahwa tingkat konsumsi kopi di Indonesia dari tahun 2016 sampai dengan tahun 2019 meningkat setiap tahunnya. Diprediksikan peningkatan ini meningkat rata-rata $8,22 \%$ setiap tahunnya. Peningkatan konsumsi kopi di Indonesia ini disebabkan salah satunya oleh gaya hidup masyarakat yang telah menjadikan minuman olahan kopi sebagai kegiatan sehari-hari dalam kebutuhan hidupnya (Solikatun dkk, 2015). Tentu saja hal ini menjadi peluang bagi para pelaku bisnis khususnya dalam bisnis usaha food service untuk mengembangkan usaha kedai kopinya.

Dewasa ini, sudah banyak sekali bisnis kedai kopi yang menjamur di kota Bandung salah satunya yaitu kafe atau 
coffee shop. Saat ini, kedai kopi selain tempat yang digunakan untuk menikmati kopi, juga dapat digunakan sebagai tempat untuk kegiatan seperti mengerjakan tugas kuliah, rapat atau berdiskusi karena terbukti kopi dapat meningkatkan konsentrasi.

Belakangan ini, terdapat kedai kopi baru yang menjadi perhatian anak muda kota Bandung, yaitu KADAKA Cafetaria. Kedai kopi yang didirikan dengan latar belakang family business ini memiliki keinginan untuk mengembangkan hobi khususnya dalam komoditas kopi. Namun, untuk sebuah perusahaan kedai kopi KADAKA Cafetaria yang masih dalam tahap pengembangan ini, persaingan yang terjadi antar sesama kedai kopi di kota Bandung terbilang sangat ketat. Hal ini dikarenakan jumlah kedai kopi yang sangat banyak, sehingga konsumen memiliki pilihan dalam memenuhi kegiatannya untuk datang ke sebuah kedai kopi. Berikut ini daftar perusahaan kedai kopi yang merupakan pesaing terdekat KADAKA Cafetaria dapat dilihat pada Tabel 1.

Tabel 1. Daftar Kedai Kopi Pesaing Terdekat KADAKA Cafetaria

\begin{tabular}{cll}
\hline No. & \multicolumn{1}{c}{ Merek Kedai Kopi } & \multicolumn{1}{c}{ Lokasi } \\
\hline 1. & Starbucks Coffee & Jl. Buah Batu No. 159 \\
2. & Coffee Bean \& Tea Leaf & Trans Studio Mall \\
3. & Excelso & Trans Studio Mall \\
4. & Aditi Coffee House and Space & Jl. K.H. Ahmad Dahlan No. 5 \\
5. & Ngopi Doeloe & Jl. Pelajar Pejuang 45 \\
6. & Marka Café & Jl. Talaga Bodas No. 32 \\
7. & 911 Coffee Lab & Jl. Palasari No. 45 \\
8. & Skola Coffee & Jl. Buah Batu No. 54 \\
9. & Kopi Bray & Jl. Talaga Bodas No. 51 \\
10. & Yellow Truck Coffee & Jl. Patuha No. 29 \\
\hline
\end{tabular}

Sumber: dari berbagai sumber (2019)

Menurut data dari Tabel 1, dengan adanya persaingan yang semakin ketat ini, pemilik/pengelola usaha kedai kopi tentu tidak hanya mampu menjual produk dan jasa nya, tetapi juga harus mempunyai kemampuan untuk memasarkan usaha mereka agar intensitas pengunjung kedai kopi mereka semakin meningkat, bukan malah sebaliknya.
Meskipun banyak bermunculan pesaing-pesaing baru, kedai kopi KADAKA Cafetaria yang masih tetap eksis dalam mempertahankan ciri khasnya dalam menghadapi kondisi persaingan antar kedai kopi yang menawarkan berupa berbagai macam minuman olahan kopi dan suasana vintage ciri khasnya. Kedai kopi kini menjadi salah satu tujuan bagi para 
pemuda dan remaja untuk mengunjungi sekedar minum kopi dan menikmati sajian juga suasana yang ada di kedai kopi.

Salah satu bisnis kedai kopi yang akan dilihat strategi pemasarannya yaitu kedai kopi KADAKA Cafetaria. Selama ini, KADAKA Cafetaria mengalami kendala dalam memasarkan produknya. Kendala yang dialami adalah keterbatasan sumber daya manusia dalam mengelola platform online khususnya sosial media, sehingga penjualan pada produk di kedai kopi ini terkesan lambat. Selain itu, kendala lain yang dihadapi yaitu munculnya pesaing yang lokasinya tepat bersebrangan dengan KADAKA Cafetaria. Tentu saja ini menjadi tuntutan bagi KADAKA Cafetaria untuk memiliki strategi yang tepat agar dapat menghadapi persaingan antar kedai kopi.

Berdasarkan uraian di atas, penting untuk dilihat mengenai kajian tentang strategi pemasaran usaha kedai kopi KADAKA Cafetaria yang terletak di kota Bandung untuk mengetahui strategi pemasaran yang dilakukan dan memberikan alternatif strategi utama yang dapat diterapkan oleh kedai kopi tersebut.

\section{METODE PENELITIAN}

Penelitian ini menggunakan desain kualitatif, dimana desain kualitatif adalah desain penelitian yang berlandaskan filsafat pospositifisme, digunakan untuk meneliti keadaan alamiah (Sugiyono, 2012). Sedangkan teknik penelitian yang digunakan dalam penelitian ini menggunakan metode studi kasus. Studi kasus menurut Creswell (2010), merupakan strategi penelitian dimana didalamnya peneliti menyelidiki secara cermat suatu program, peristiwa, aktivitas, proses, atau sekelompok individu.

\section{Analisis Matriks IFE (Internal Factor Evaluation).}

Menurut David (2009), analisis internal dilakukan untuk mengetahui kekuatan dan kelemahan yang dimiliki oleh perusahaan.

\section{Analisis Matriks EFE (External Factor Evaluation).}

Menurut David (2009), analisis eksternal dilakukan untuk mengetahui peluang dan ancaman yang dimiliki oleh perusahaan.

\section{Matriks IE (Internal-External)}

Tahap ini merupakan tahap pencocokan dengan memasukkan hasil pembobotan matriks IFE dan EFE kedalam matriks IE. Menurut David (2009), hal ini bertujuan untuk 
memperoleh strategi bisnis di tingkat korporat yang lebih detail. Matriks IE merupakan hasil penggabungan antara matriks IFE dan matriks EFE ke dalam matriks yang terdiri dari sembilan sel.

Matriks IE memiliki tiga implikasi utama yang mempunyai dampak strategi berbeda, yaitu Growth and Build (tumbuh dan bina) berada dalam sel I, II, IV. Strategi yang cocok adalah intensif seperti penetrasi pasar, pengembangan pasar atau pengembangan produk, dan strategi terintegrasi seperti integrasi ke belakang, integrasi kedepan dan integrasi horizontal. Hold and Maintain (pertahankan dan pelihara) dilakukan untuk sel III, V danVII. Strategi umum dipakai yaitu strategi penetrasi pasar dan pengembangan produk, dan yang terakhir adalah Harvest or Divest (panen atau divestasi) dipakai untuk sel VI, VIII, IX. Strategi umum yang dipakai adalah strategi divestasi, strategi diversifikasi konglomerat, dan strategi likuidasi.

\section{Matriks SWOT (Strength, Weakness, Opportunities, Threats)}

Menurut Rangkuti (2006), merupakan alat pencocokan yang digunakan dalam mengidentifikasi berbagai faktor secara sistematis untuk merumuskan strategi perusahaan. Matriks ini menggambarkan bagaimana peluang dan ancaman eksternal yang dihadapi perusahaan dapat disesuaikan dengan kekuatan dan kelemahan yang dimilikinya.

\section{Matriks QSP (Quantitative Strategic Planning) \\ Menurut David (2009), analisis} matriks QSP digunakan untuk mengevaluasi strategi secara objektif berdasarkan faktor-faktor sukes utama internal-eksternal (IE) yang telah diidentifikasi pada tahap sebelumnya. Teknik ini secara objektif menunjukkan strategi mana yang terbaik.

\section{HASIL DAN PEMBAHASAN}

\section{Analisis Matriks IFE}

Berdasarkan hasil analisis dari matriks IFE pada Tabel 2. dapat diketahui bahwa faktor yang menjadi kekuatan utama perusahaan yaitu "kualitas beans yang bagus dan terjamin" dengan perolehan skor 0,336. Sedangkan faktor yang menjadi kelemahan utama perusahaan yaitu "kegiatan promosi belum dilakukan secara maksimal" dengan perolehan skor 0,083 . Total skor dari matriks IFE sejumlah 3,14 yang menandakan bahwa faktor internal KADAKA Cafetaria berada pada posisi kuat dalam memanfaatkan kekuatan dan mengatasi kelemahan. 
Tabel 2. Hasil Analisis Matriks IFE KADAKA Cafetaria

\begin{tabular}{clccc}
\hline No & \multicolumn{1}{c}{ Faktor-Faktor Internal } & Bobot & Rating & Skor \\
\hline & \multicolumn{1}{c}{ Kekuatan } & & & 0,213 \\
1 & Harga terjangkau di kalangan masyarakat & 0,061 & 3,5 & 0,312 \\
2 & Suasana kedai kopi homie dan nyaman & 0,078 & 4,0 & 0,214 \\
3 & Menggunakan alat pembayaran Go-Pay dan mendapatkan & 0,065 & 3,3 & 0,234 \\
4 & cashback & 0,067 & 3,5 & 0,250 \\
5 & Kudah memiliki pelanggan tetap & 0,066 & 3,8 & 0,255 \\
6 & Pelayanan terhadap konsumen sigap dan ramah & 0,071 & 3,6 & 0,207 \\
7 & Menu beragam & 0,063 & 3,3 & 0,221 \\
8 & Terdapat 2 produk andalan & 0,067 & 3,3 & 0,336 \\
9 & Kualitas beans bagus dan terjamin & 0,084 & 4,0 & 0,304 \\
10 & Konsep kedai kopi yang menarik & 0,076 & 4,0 & 0,323 \\
11 & Bahan baku yang terjamin kesegaran dan kualitasnya & 0,085 & 3,8 & \\
\hline & & & & 0,061 \\
\hline 1 & Lokasi bersebrangan dengan kedai kopi lain & 0,047 & 1,3 & 0,083 \\
2 & Kegiatan promosi penjualan belum maksimal & 0,083 & 1,0 & 0,127 \\
3 & Belum adanya admin khusus untuk sosial media & 0,071 & 1,8 \\
\hline
\end{tabular}

\section{Analisis Matriks EFE}

Berdasarkan hasil analisis dari matriks EFE pada Tabel 3. dapat diketahui bahwa faktor yang menjadi peluang utama perusahaan yaitu "adanya ekspansi (peluang) usaha" dengan perolehan skor 0,455. Sedangkan faktor yang menjadi ancaman utama perusahaan yaitu "adanya tingkat persaingan kedai kopi yang tinggi" dengan perolehan skor 0,401. Total skor dari matriks EFE sejumlah 3,195 yang menandakan bahwa faktor eksternal KADAKA Cafetaria berada pada posisi kuat dalam merespon peluang dan menghindari ancaman.

\section{Tabel 3. Hasil Analisis Matriks EFE KADAKA Cafetaria}

\begin{tabular}{|c|c|c|c|c|}
\hline No & Faktor-Faktor Eksternal & Bobot & Rating & Skor \\
\hline \multicolumn{5}{|c|}{ Peluang } \\
\hline 1 & Perkembangan teknologi yang semakin maju & 0,117 & 3,83 & 0,448 \\
\hline 2 & Loyalitas pelanggan (ada hubungan baik) & 0,100 & 3,83 & 0,383 \\
\hline 3 & Perubahan gaya hidup masyarakat & 0,108 & 3,16 & 0,341 \\
\hline 4 & Kondisi perekonomian masyarakat sekitar lokasi yang baik & 0,102 & 2,30 & 0,234 \\
\hline 5 & Adanya pembayaran elektronik lainnya (ovo, t-cash, dll) & 0,120 & 3,33 & 0,399 \\
\hline 6 & Ekspansi (peluang) usaha & 0,130 & 3,50 & 0,455 \\
\hline \multicolumn{5}{|c|}{ Ancaman } \\
\hline 1 & Harga bahan baku yang tidak stabil & 0,097 & 2,83 & 0,274 \\
\hline 2 & Tingkat persaingan kedai kopi yang tinggi & 0,127 & 3,16 & 0,401 \\
\hline 3 & Adanya usaha kuliner substitusi & 0,092 & 2,83 & 0,260 \\
\hline \multicolumn{2}{|r|}{ Total } & 1,000 & 28,77 & 3,195 \\
\hline
\end{tabular}




\section{Analisis Matriks IE}

Matriks IE memiliki tiga implikasi strategi yang berbeda tergantung dari posisi perusahaan itu berada. Berdasarkan hasil skor pada Tabel 2. dan Tabel 3. total matriks IFE sebesar 3,14 dan total matriks EFE sebesar 3,195.
Setelah total skor matriks IFE dan EFE diketahui, maka dari hasil total skor tersebut dapat ditentukan posisi strategis KADAKA Cafetaria melalui analisis matriks IE yang dapat ditunjukkan pada Gambar 2.

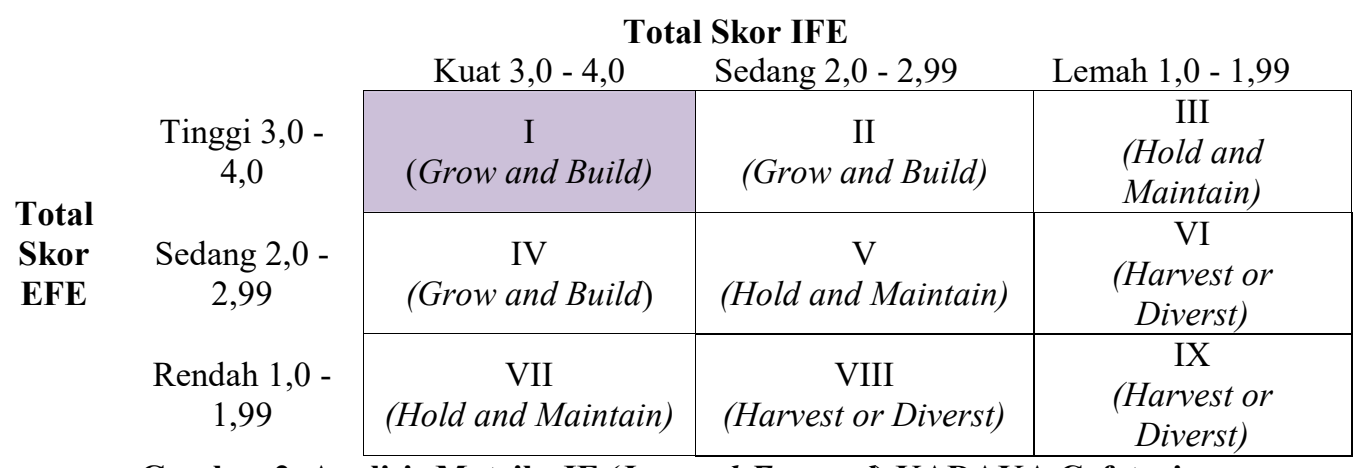

Gambar 2. Analisis Matriks IE (Internal-External) KADAKA Cafetaria

Hasil matriks IE menunjukkan bahwa KADAKA Cafetaria berada pada sel I (grow and build). Strategi yang cocok pada posisi sel ini bagi KADAKA Cafetaria adalah strategi intensif (penetrasi pasar, pengembangan produk, dan pengembangan pasar) atau strategi integratif (integrasi ke belakang, integrasi ke depan, dan integrasi horizontal).

Alternatif strategi yang dapat dilakukan oleh KADAKA Cafetaria yaitu strategi yang dapat dilakukan oleh KADAKA Cafetaria berupa strategi intensif. Penetrasi pasar yang dapat dilakukan yaitu dengan mencari pasar yang lebih luas untuk memasarkan produk atau jasa yang ada melalui kegiatan pemasaran yang lebih gencar seperti menambah jumlah tenaga penjualan, meningkatkan anggaran untuk periklanan, promosi penjualan secara intensif, dan peningkatan penawaran produk. Sedangkan pengembangan pasar, hal ini dapat dilakukan dengan cara memperkenalkan produk atau jasa ke pasar potensial yang baru. Hal yang dapat dilakukan yaitu dengan membuka cabang baru di daerah yang potensial. 


\section{Analisis Matriks SWOT}

Matriks SWOT merupakan sebuah alat analisis yang dapat digunakan untuk mengetahui strategi perusahaan yang sedang dilakukan dan juga dapat digunakan untuk menghasilkan alternatif strategi bagi perusahaan.

Tabel 4. Analisis Matriks SWOT pada KADAKA Cafetaria

\section{Kekuatan \\ (Strength-S)}

1. Harga terjangkau di kalangan masyarakat

2. Suasana kedai kopi homie dan nyaman

3. Menggunakan pembayaran Go-Pay dan mendapatkan cashback

4. Sudah memiliki pelanggan tetap

5. Ketersediaan fasilitas lengkap (wifi, toilet, musholla)

6. Pelayanan terhadap konsumen sigap dan ramah

7. Menu beragam

8. Terdapat 2 produk andalan

9. Kualitas beans bagus dan terjamin

10. Konsep kedai kopi yang menarik

11. Bahan baku yang terjamin kesegaran dan kualitasnya

\section{Peluang (Opportunities-O)}

1. Perkembangan tek nologi yang semakin maju

2. Loyalitas pelanggan (ada hubungan baik)

3. Perubahan gaya hidup masyarakat

4. Kondisi perekonomian masyarakat sekitar lokasi yang baik

5. Adanya pembayaran elektronik lainnya (ovo, t-cash, dll)

6. Ekspansi (peluang) usaha

\section{Ancaman \\ (Threats-T)}

1. Harga bahan baku yang tidak stabil

2. Tingkat persaingan kedai kopi yang tinggi

3. Adanya usaha kuliner substitusi
Memperluas distribusi penjualan dengan membuka cabang baru di daerah lain

(S2, S5, S6, S7, S8, S9, S10, O2,$$
\text { S9, S10, O2, }
$$

$$
\text { O3, O6) }
$$

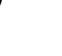

\section{Kelemahan \\ (Weakness-W)}

1. Lokasi bersebrangan dengan kedai kopi lain

2. Kegiatan promosi penjualan belum maksimal

3. Belum adanya admin khusus untuk sosial media
Strategi W-O

Meningkatkan promosi penjualan (W2, W3, O1) 


\section{Analisis Matriks QSP}

Matriks QSP adalah alat analisis yang menentukan prioritas alternatif strategi yang dapat dijalankan perusahaan dari alternatif- alternatif strategi yang diperoleh dari hasil analisis matriks SWOT. Dari hasil analisis SWOT, dihasilkan 4 alternatif strategi. Selanjutnya, diberikan nilai Attractive Score (AS) dengan mencocokkan faktorfaktor strategis internal dan eksternal yang dapat memengaruhi alternatif strategi. Setelah itu, dilakukan perkalian antara nilai AS dengan bobot rata-rata dari faktor kunci untuk menghasilkan TAS (Total Attractiveness Score). Nilai
TAS dijumlahkan secara vertikal untuk memperoleh jumlah total daya tarik atau STAS (Sum Total Attractiveness Scores). Nilai STAS tertinggi akan menjadi prioritas strategi yang menarik untuk dijalankan oleh pihak KADAKA Cafetaria.

Berdasarkan hasil analisis matriks QSP, dapat dilihat bahwa strategi yang menjadi prioritas yang harus segera dilaksanakan oleh KADAKA Cafetaria adalah meningkatkan promosi dengan cara memanfaatkan sosial media dan event tertentu, serta promosi dalam bentuk pemberian diskon dan harga spesial di hari tertentu.

Tabel 5. Analisis Matriks QSP pada KADAKA Cafetaria

\begin{tabular}{clc}
\hline No & \multicolumn{1}{c}{ Alternatif Strategi } & $\begin{array}{c}\text { Total Nilai Daya } \\
\text { Tarik (TAS) }\end{array}$ \\
\hline 1 & $\begin{array}{l}\text { Meningkatkan kegiatan promosi dengan cara memanfaatkan media } \\
\text { sosial dan event terterntu, serta promosi dalam bentuk pemberian diskon } \\
\text { dan harga spesial di hari tertentu }\end{array}$ & 7,090 \\
2 & $\begin{array}{l}\text { Mempertahankan ciri khas kedai kopi } \\
\text { Memperluas distribusi penjualan dengan membuka cabang baru di } \\
\text { daerah lain }\end{array}$ & 6,012 \\
4 & $\begin{array}{l}\text { Mengembangkan produk dengan menambah variasi produk pada menu } \\
\text { secara berkala }\end{array}$ & 5,951 \\
\hline
\end{tabular}

\section{KESIMPULAN DAN SARAN}

Hasil penelitian berdasarkan matriks yang sudah dianalisis yaitu:

1. Pada faktor kekuatan di KADAKA Cafetaria, terdapat kekuatan utama yakni kualitas beans yang bagus dan terjamin sedangkan pada faktor kelemahan utama yakni kegiatan promosi belum dilakukan secara maksimal. Lalu, pada faktor peluang, terdapat peluang utama yakni adanya ekspansi (peluang) usaha. Sedangkan pada faktor ancaman utama, yakni adanya tingkat persaingan kedai kopi yang tinggi.

2. Terdapat 4 alternatif strategi pemasaran yang dapat diterapkan oleh KADAKA Cafetaria, yaitu 
memperluas distribusi penjualan dengan membuka cabang baru di daerah lain, meningkatkan promosi penjualan, mengembangkan produk, dan mempertahankan ciri khas kedai kopi.

3. Rumusan strategi yang dapat diprioritaskan dari hasil analisis matriks QSP adalah meningkatkan dengan kegiatan promosi dengan cara memaksimalkan pemanfaatan media sosial yang dimiliki KADAKA Cafetaria dan ikut berpartisipasi pada event tertentu, lalu memberikan promosi dalam bentuk pemberian diskon dan harga spesial pada hari tertentu. Strategi ini dirumuskan sebagai upaya meningkatkan serta memperluas jangkauan pemasaran dari KADAKA Cafetaria.

\section{DAFTAR PUSTAKA}

Afriyanti, Sintia. 2016. Studi Strategi Pemasaran Terbaik Berdasarkan Perilaku Konsumen dalam Menghadapi Persaingan Antar Kedai Kopi di Jatinangor. Skripsi. Program Studi Agribisnis Fakultas Pertanian Universitas Padjadjaran.

David, Fred. R. 2009. Manajemen Strategis Konsep, Edisi 12. Jakarta: Salemba Empat.

Direktorat Jendral Perkebunan. 2018. Statistik Perkebunan Indonesia Komoditas Kopi 2015-2017. Kementrian Pertanian. Jakarta.

Siswoputranto, P.S. 1992. Kopi Internasional dan Indonesia. Kanisius: Yogyakarta.

Solikatun, Drajat Tri Kartono, dan Argyo Demartoto. 2015. Perilaku Konsumsi Kopi Sebagai Budaya Masyarakat Konsumsi: Studi Fenomenologi Pada Peminum Kopi di Kedai Kopi Kota Semarang. Jurnal Analisa Sosiologi, April 2015, 4(1): 60-74.

Sugiyono, 2013. Metode Penelitian Kuantitatif, Kualitatif dan $R \& D$. Bandung: Alfabeta.

Creswell, J.W. 2010. Research design: pendekatan kualitatif, kuantitatif dan mixed. Yogyakarta: PT. Pustaka Belajar. 